\title{
Zmiany budżetu jednostki samorządu terytorialnego w toku jego wykonywania - zakres, kompetencje
}

\section{Wprowadzenie}

Budżet jednostki samorządu terytorialnego (JST), jako publiczny plan finansowy, jest opracowywany, uchwalany i wykonywany w sposób przewidziany prawem i przy respektowaniu określonych wymogów odnoszących się do szczególnych jego właściwości i pożądanych cech. Przepisy prawa dzielą uprawnienia do podejmowania określonych czynności w toku procedury budżetowej między organ stanowiący a organ wykonawczy. Mamy tu do czynienia z przemiennością kompetencji w trakcie podstawowych faz procedury budżetowej ${ }^{1}$. Przygotowanie projektu budżetu należy do kompetencji organu wykonawczego, a jego uchwalenie w formie uchwały budżetowej - do organu stanowiącego, zaś wykonywanie - do organu wykonawczego JST. Rozdzielenie kompetencji nie ma jednak charakteru pełnego $\mathrm{w}$ tym znaczeniu, że przepisy regulujące procedurę budżetową przewidują w określonych przypadkach ograniczenia uprawnień organu odgrywającego wiodącą rolę w danej fazie na rzecz drugiego organu. I tak, organ stanowiący nie może uchwalić budżetu z deficytem większym niż zaprojektowany przez organ wykonawczy, zaś uprawnienia organu wykonawczego w zakresie wykonywania budżetu ulegają ograniczeniu przez organ stanowiący w związku $\mathrm{z}$ dokonywaniem określonych zmian w budżecie.

Proces wykonywania budżetu obejmuje całokształt czynności faktycznych i prawnych, których przedmiotem jest realizacja zadań ujętych w budżecie ${ }^{2}$.

* Prof. nadzw. dr hab. Krystyna Sawicka - Katedra Prawa Finansowego, Wydział Prawa, Administracji i Ekonomii, Uniwersytet Wrocławski.

${ }^{1}$ Zob. E. Kornberger-Sokołowska, Budżety jednostek samorzadu terytorialnego $w$ aspekcie decentralizacji i regionalizacji finansów publicznych, [w:] T. Dębowska-Romanowska et al., System prawa finansowego, t. 2: E. Ruśkowski (red.), Prawo finansowe sektora finansów publicznych, Warszawa 2010, s. 257.

2 Zob. szerzej: J. Glumińska-Pawlic, K. Sawicka, Budżet jednostki samorządu terytorialnego, Zielona Góra 2002, s. 221 i n.; E. Kornberger-Sokołowska, Finanse jednostek samorządu terytorialnego, [w:] E. Chojna-Duch, H. Litwińczuk (red.), Prawo finansowe, Warszawa 2010, s. 185 i n.; 
Wspomniane czynności są zróżnicowane i obejmują zarówno te o charakterze instrumentalnym, zmierzające pośrednio do zapewnienia realizacji dochodów i wydatków oraz przychodów i rozchodów ustalonych w budżecie, jak i czynności polegające na gromadzeniu dochodów i przychodów budżetowych oraz na dokonywaniu wydatków ze środków zgromadzonych w budżecie i rozchodów ${ }^{3}$. W ramach czynności instrumentalnych można wyodrębnić te, które polegają na planowaniu wykonywania zadań ustalonych w budżecie - dotyczą one przygotowania planu wykonawczego budżetu, opracowania planu finansowego zadań z zakresu administracji rządowej oraz innych zadań zleconych JST ustawami, czy też organizowania i koordynacji procesu pobierania dochodów i dokonywania wydatków budżetowych (opracowanie harmonogramu realizacji dochodów i wydatków budżetu). Drugą ważną grupę stanowią czynności instrumentalne, których zadaniem jest przeciwdziałanie ujemnym skutkom deformacyjnego działania upływu czasu w stosunku do zaplanowanych w budżecie zadań, usuwanie następstw błędnych ustaleń zadań budżetowych, a także uwzględnianie skutków zmian natury organizacyjnej. Czynności tego rodzaju służą korygowaniu zadań ustalonych w budżecie i znajdują wyraz w takich instytucjach, jak rezerwy budżetowe, przenoszenie wydatków budżetowych oraz blokowanie wydatków budżetowych. Instrumentalny charakter mają także czynności obsługi kasowej budżetu, których zakres jest szerszy niż tylko przyjmowanie wpłat i dokonywanie wypłat pieniężnych z rachunków, na których gromadzone są środki budżetowe.

Funkcją czynności instrumentalnych jest stworzenie warunków niezbędnych do prawidłowego prowadzenia procesu wykonywania budżetu, głównie zaś określenie ram działalności jednostek budżetowych realizujących dochody i wydatki budżetowe. Obowiązek ten spoczywa na zarządzie JST jako wykonawcy budżetu i jednocześnie sprawującym ogólny nadzór nad realizacją określonych uchwałą budżetową dochodów i wydatków, przychodów i rozchodów budżetu JST. Podstawę prawną podejmowania czynności instrumentalnych oraz czynności związanych bezpośrednio z wykonywaniem budżetu stanowią przepisy ustaw o ustroju samorządu terytorialnego ${ }^{4}$ i ustawy o finansach publicznych ${ }^{5}$ (zwłaszcza

K. Ostrowski, Prawo finansowe. Zarys ogólny, Warszawa 1970, s. 248 i n.; E. Ruśkowski, Zasady wykonywania budżetów samorządowych, [w:] C. Kosikowski, E. Ruśkowski (red.), Finanse publiczne i prawo finansowe, wyd. 3, Warszawa 2008, s. 367 i n.; J. Salachna, Odpowiedzialność za nieprzestrzeganie procedury tworzenia $i$ wykonywania budżetu jednostki samorzadu terytorialnego, Warszawa 2008, s. 251 i n.

3 Zob. szerzej: A. Kostecki, Wykonywanie budżetu, [w:] M. Weralski (red.), System instytucji prawno-finansowych PRL, t. II: Instytucje budzetowe, cz. I, Wrocław 1982, s. 476 i n.

4 Ustawa z dnia 8 marca 1990 r. o samorządzie gminnym, Dz. U. z 2001 r. Nr 142, poz. 1591 ze zm. (dalej u.s.g.); ustawa z dnia 5 czerwca 1998 r. o samorządzie powiatowym, Dz. U. z 2001 r. Nr 142, poz. 1592 ze zm. (dalej u.s.p.); ustawa z dnia 5 czerwca 1998 r. o samorządzie województwa, Dz. U. z 2001 r. Nr 142, poz. 1590 ze zm. (dalej u.s.w.).

5 Ustawa z dnia 27 sierpnia 2009 r. o finansach publicznych, Dz. U. Nr 157, poz. 1240 ze zm. (dalej u.f.p.). 
Rozdział 4 „Wykonywanie budżetu jednostki samorządu terytorialnego” Działu V „Budżet, wieloletnia prognoza finansowa i uchwała budżetowa jednostki samorządu terytorialnego", przy uwzględnieniu ogólnych zasad gospodarowania środkami publicznymi, uregulowanych w Rozdziale 5 „Przepisy ogólne” Działu I „Zasady finansów publicznych”) oraz przepisy wykonawcze do tej ustawy, a także przepisy ustaw szczegółowych określające tytuły prawne do pobierania dochodów ze źródeł przypisanych JST poszczególnych szczebli i do dokonywania wydatków zaplanowanych w budżecie na konkretne zadania. Przepisy te w swoim całokształcie określają zasady, instytucje i procedury obowiązujące w toku wykonywania budżetu.

\section{Przesłanki i zakres zmian budżetu}

O konieczności dokonywania zmian budżetu w ciągu roku budżetowego decyduje wiele zróżnicowanych przesłanek, takich jak zmiana wysokości dochodów przekazywanych z budżetu państwa, zmiany natury organizacyjnej, błędne ustalenie zadań budżetowych, czy też konieczność korekty tych zadań pod wpływem zmieniających się w czasie warunków ich realizacji. Zmiany budżetu wymaga także możliwość wykorzystania w roku budżetowym dochodów zrealizowanych w kwocie wyższej niż pierwotnie zaplanowana. Potrzeba zmiany może również zaistnieć w przypadku znacznie niższego poziomu realizacji dochodów budżetowych w stosunku do dochodów zaplanowanych. W takiej sytuacji dla zachowania równowagi budżetowej należy obniżyć odpowiednio dochody i wydatki budżetu, albo też, obniżając dochody, zwiększyć deficyt budżetowy, wskazując przy tym źródła jego pokrycia. Powodem korekty budżetu może być także konieczność sfinansowania nowych zadań, jakie pojawiły się w trakcie roku budżetowego, a uchwalona w budżecie rezerwa ogólna jest niewystarczająca, aby zadania te zrealizować, lub też została już w całości rozdysponowana.

Zmiany budżetu JST w procesie jego wykonywania mogą przybierać postać dwojakiego rodzaju - mogą to być zmiany budżetu i zmiany w budżecie. Zmiany budżetu dotyczą zmian wysokości zarówno dochodów, jak i wydatków budżetowych w ich globalnym ujęciu w stosunku do wielkości pierwotnie uchwalonych przez organ stanowiący JST w uchwale budżetowej oraz powiązanych z tymi wielkościami zmian wyniku budżetu, jego przychodów i rozchodów, a w efekcie także kwoty długu. Natomiast w przypadku zmian w budżecie globalna kwota uchwalonych pierwotnie dochodów i wydatków budżetowych nie ulega zmianie. Przez zmiany w budżecie koryguje się wcześniej ustalone limity na poszczególne rodzaje wydatków. Zmiany te znajdują wyraz w takich instytucjach, jak: przenoszenie wydatków budżetowych pomiędzy podziałkami klasyfikacji budżetowej, zwiększenie wydatków na poszczególne zadania w granicach ustalonych w budżecie rezerw oraz blokowanie wydatków budżetowych. Zmiany budżetu w trak- 
cie roku budżetowego mogą być dokonywane wyłącznie z inicjatywy zarządu JST (art. 233 u.f.p.). Jak wynika ze sprawozdania opracowanego przez Krajową Radę Regionalnych Izb Obrachunkowych ${ }^{6}$, w 2010 r. liczba uchwał i zarządzeń zmieniających budżet, podjętych przez organy JST wynosiła w skali kraju aż 95828 i była o 10,7\% większa niż w 2009 r. (86 570 uchwał i zarządzeń). Trzon tych zmian stanowiły zmiany budżetu i zmiany w budżecie w formie przeniesień wydatków budżetowych, w tym również w ramach rozdysponowania rezerw budżetowych. Natomiast blokowanie wydatków budżetowych miało charakter incydentalny, bowiem w 2010 r. podjęto zaledwie 5 uchwał i zarządzeń tego rodzaju (w 2009 r. -6 , w 2008 r. -6$)^{7}$.

\section{Zmiany $w$ budżecie $w$ formie rozdysponowania rezerw i zablokowania wydatków budżetowych}

Instytucje rezerw budżetowych oraz blokowania wydatków budżetowych są powiązane funkcjonalnie $\mathrm{z}$ procedurą wykonywania budżetu w części odnoszącej się do zmian w budżecie JST. W budżecie JST tworzy się rezerwę ogólną, która ma charakter obligatoryjny, a także fakultatywne rezerwy celowe w granicach ustawowo określonych limitów (art. 222 u.f.p.). Posiadanie rezerw ma służyć zapewnieniu elastyczności realizacji budżetu przez organ wykonawczy samorządu. Rezerwy zabezpieczają środki finansowe na wypadek konieczności poniesienia wydatków, które w budżecie nie zostały w ogóle zaplanowane lub zostały zaplanowane w kwocie niewystarczającej do pełnego zrealizowania określonego zadania (rezerwa ogólna), albo wydatków, których ogólne przeznaczenie jest znane, ale których szczegółowy podział będzie mógł być dokonany dopiero w trakcie roku budżetowego z chwilą przystąpienia do realizacji zadania (rezerwy celowe). Funkcjonowanie instytucji rezerw budżetowych jest wyjątkiem od zasady szczegółowości budżetu. Rezerwa stanowi bowiem odstępstwo od postulatu, aby dochody i wydatki budżetu, odpowiednio do przepisów o klasyfikacji budżetowej, nie były planowane w budżecie w kwotach globalnych, ale przypisane do poszczególnych zdań samorządu ${ }^{8}$.

Rezerwami utworzonymi w budżecie dysponuje organ wykonawczy JST, dokonując ich podziału przez odpowiednie zmiany w budżecie, polegające na przeniesieniu środków finansowych z rezerw na zwiększenie planu wydatków w określonych podziałkach klasyfikacji budżetowej bądź na stworzeniu planu wydatków

${ }^{6}$ Krajowa Rada Regionalnych Izb Obrachunkowych, Sprawozdanie z działalności regionalnych izb obrachunkowych $i$ wykonania budżetu przez jednostki samorzadu terytorialnego w 2010 roku, Warszawa 2011, s. 131 i n.

7 Ibidem, s. 132.

${ }^{8}$ Zob. wyrok WSA w Poznaniu z dnia 12 października 2005 r., I SA/PO 919/05; orzecznictwo. nsa.gov.pl. 
wcześniej w budżecie nieprzewidzianych, a następnie wykonaniu tak zaplanowanych wydatków. Orzecznictwo sądów administracyjnych dopuszcza też dysponowanie rezerwami przez organ stanowiący, pod warunkiem jednak, że ma to podstawę $\mathrm{w}$ inicjatywie takiej zmiany w budżecie, pochodzącej od organu wykonawczego9. Podobnie nie kwestionuje się również możliwości zwiększenia rezerw w trakcie roku budżetowego przez organ stanowiący samorządu ${ }^{10}$. Wydatki przenoszone z rezerwy ogólnej nie mogą zwiększać planowanych wydatków na uposażenia i wynagrodzenia ze stosunku pracy, o ile odrębne przepisy nie stanowią inaczej. Rezerwy celowe mogą być przeznaczone wyłącznie na cel, na jaki zostały utworzone, oraz wykorzystane zgodnie z klasyfikacją budżetową wydatków. Zarząd może jednak, po uzyskaniu pozytywnej opinii komisji właściwej do spraw budżetu organu stanowiącego JST, dokonać zmiany przeznaczenia rezerwy celowej (art. 259 u.f.p.).

Zmiana w budżecie JST poprzez zablokowanie planowanych wydatków budżetowych może nastąpić w przypadkach określonych w art. 260 ust. 1 u.f.p., dotyczących naruszenia zasady gospodarności i prawnie określonych reguł wydatkowania środków publicznych. Decyzja o blokowaniu może być bowiem podjęta w razie stwierdzenia niegospodarności w określonych jednostkach, opóźnień w realizacji zadań, nadmiaru posiadanych środków oraz naruszenia zasad gospodarki finansowej obowiązujących w toku wykonywania budżetu. Blokowanie oznacza okresowy lub obowiązujący do końca roku zakaz dysponowania przez jednostkę wykonującą budżet (jednostkę budżetową) częścią lub całością wydatków danego rodzaju zaplanowanych dla niej w budżecie. Decyzja o blokowaniu może dotyczyć ostatecznego cofnięcia (do końca roku) uprawnień do wykorzystania określonych środków budżetowych w całości lub w części. W pierwszym wypadku zablokowanie wydatków budżetowych powoduje taki sam skutek, jak instytucja wygaśnięcia wydatków z upływem roku budżetowego. W drugim zaś przypadku następuje ograniczenie zakresu uprawnień do wykorzystania środków budżetowych (zmniejszenie wydatków). Blokowanie może polegać także na jedynie przejściowym pozbawieniu dysponenta wydatków budżetowych uprawnień do rozporządzania środkami budżetowymi, oznaczające w praktyce zawieszenie tych uprawnień na pewien czas, po upływie którego uprawnienia te odzyskują swoją moc. Instytucja blokowania planowanych wydatków budżetowych powinna sprzyjać racjonalnemu wykorzystaniu środków publicznych.

Decyzje o blokowaniu wydatków podejmuje zarząd JST, który ma jednocześnie obowiązek poinformowania o tym organu stanowiącego. Nałożenie takiego obowiązku umożliwia bieżącą kontrolę przez radę (sejmik) decyzji zarządu podjętych w tym zakresie. Blokowanie planowanych wydatków budżetowych jest uprawnieniem, a nie obowiązkiem zarządu JST. Jego działanie powinno być opar-

\footnotetext{
9 Zob. wyrok NSA z dnia 20 stycznia 2010 r., II GSK 276/09, LEX nr 1103615.

${ }_{10}$ Zob. wyrok NSA z dnia 2 października 2002 r., I SA/GD 1245/02, OwSS 2004, nr 2, poz. 48.
} 
te na ocenie gospodarki finansowej i realizacji zadań przez jednostkę budżetową, której wydatki zostają zablokowane, bowiem podjęta decyzja musi mieć merytoryczne uzasadnienie.

Wykorzystanie zablokowanej kwoty wydatków przez zarząd będzie możliwe tylko wtedy, kiedy wystapi on $\mathrm{z}$ inicjatywą utworzenia z tych środków nowej rezerwy celowej na finansowanie zobowiązań JST i uzyska pozytywną opinię komisji właściwej do spraw budżetu organu stanowiącego JST. Utworzenie rezerwy nastąpi w drodze przeniesienia przez organ wykonawczy na jej rzecz zablokowanych wydatków budżetowych, czyli przez dokonanie zmian w budżecie. Jeżeli natomiast zarząd z taką inicjatywą nie wystąpi albo też nie uzyska aprobującej opinii w sprawie utworzenia rezerwy celowej, kwota zablokowanych wydatków nie będzie mogła być wykorzystana w danym roku budżetowym, a będzie miała jedynie wpływ na ostateczny wynik wykonania budżetu w tym roku.

\section{Zmiany budżetu i zmiany $w$ budżecie $w$ formie przenoszenia wydatków budżetowych}

Uzasadnieniem dla łącznego rozpatrywania zmian budżetu i zmian w budżecie w formie przeniesień wydatków budżetowych jest przeplatanie się kompetencji organów JST do dokonywania tego rodzaju zmian. Zmiany budżetu, co do zasady, należą do właściwości organu stanowiącego JST, co wynika z wyłącznej kompetencji tego organu do uchwalania budżetu. Ustawa o finansach publicznych przewiduje też szczególne sytuacje, kiedy zmian budżetu dokonuje zarząd, działając na podstawie wyraźnego upoważnienia ustawowego. Regulacje tego rodzaju zawiera art. 257 u.f.p., z którego wynikają kompetencje zarządu do zmian planu dochodów i wydatków budżetu JST związanych ze zmianą kwot lub uzyskaniem dotacji, albo też ze zwrotem dotacji wcześniej otrzymanych, oraz do zmian planu dochodów, wynikających ze zmian kwot subwencji w wyniku podziału rezerw subwencji ogólnej. Podobnie kompetencje do dokonywania zmian w budżecie w formie przenoszenia wydatków budżetowych zostały rozdzielone między organy JST. Do przenoszenia wydatków między działami klasyfikacji budżetowej właściwy jest organ stanowiący, a w zakresie dokonywania innych zmian - także zarząd JST działający albo na podstawie upoważnienia ustawowego, albo na podstawie upoważnienia udzielonego przez organ stanowiący w uchwale budżetowej.

Przenoszenie wydatków budżetowych pomiędzy podziałkami klasyfikacji budżetowej jest najpowszechniej dokonywaną w trakcie roku budżetowego zmianą w budżecie. Zarząd JST z mocy ustawy (art. 257 pkt 3 u.f.p.) uzyskał prawo do wprowadzania zmian w planie wydatków w ramach działu, ale tylko w zakresie wydatków bieżących, z wyjątkiem zmian planu wydatków na uposażenia i wynagrodzenia ze stosunku pracy, o ile odrębne przepisy nie stanowią inaczej. 
Na podstawie art. 258 ust. 1 pkt 1 u.f.p. kompetencje zarządu JST do dokonywania zmian w planie wydatków budżetu mogą ulec rozszerzeniu w oparciu o odpowiednie upoważnienia udzielone przez organ stanowiący. Przedmiotem tych upoważnień mogą być inne zmiany niż określone ustawowo w art. 257 u.f.p., z wyłączeniem przeniesień wydatków między działami. A zatem zarząd może zostać upoważniony do dokonywania zmian w ramach działu, dotyczących zarówno planu wydatków na wynagrodzenia, jak i planu wydatków majątkowych.

Przenoszenie wydatków między działami pozostaje w wyłącznej kompetencji organu stanowiącego. Organ stanowiący, udzielając zarządowi JST upoważnienia, musi wskazać, jakiego rodzaju zmian w planie wydatków to upoważnienie dotyczy i ewentualnie może określić warunki ich dokonywania. Zarząd może zostać upoważniony do wprowadzania zmian w budżecie, polegających na przenoszeniu wydatków pomiędzy rozdziałami i paragrafami w obrębie tego samego działu klasyfikacji budżetowej, zarówno w planie wydatków bieżących na uposażenia i wynagrodzenia, jak i w planie wydatków majątkowych oraz pomiędzy planem wydatków bieżących a planem wydatków majątkowych.

Zmiany $\mathrm{w}$ formie przeniesień planowanych wydatków budżetowych naruszają pierwotną strukturę wydatków określoną w uchwale budżetowej i dlatego dokonywanie tego rodzaju zmian może podlegać pewnym ograniczeniom. Mogą być to ograniczenia dotyczące przedmiotu i wysokości kwot przeniesień oraz czasu ich dokonywania. Ograniczenia o charakterze przedmiotowym wyłączają wskazane rodzaje wydatków z możliwości zmiany ich kwot w drodze przeniesień. Ograniczenia te mogą dotyczyć np. wydatków majątkowych przeznaczonych na programy finansowane z udziałem środków unijnych. Ograniczenia rozmiarów przeniesień polegają natomiast na tym, że zwiększenie lub zmniejszenie wydatków tą drogą nie może przekroczyć określonego odsetka ich pierwotnej kwoty. Wreszcie ograniczenia odnośnie do czasu dokonywania przeniesień dopuszczają takie działania tylko w określonym przedziale roku budżetowego, wprowadzając z reguły zakaz ich podejmowania na początku i na końcu roku budżetowego. Dokonywanie zmian w planie określonych wydatków organ stanowiący może poza tym uzależnić od opinii właściwej komisji rady (sejmiku), może też wprowadzić obowiązek informowania komisji do spraw budżetu o dokonanych zmianach.

Organ stanowiący może także upoważnić zarząd do przekazania niektórych uprawnień do dokonywania przeniesień planowanych wydatków kierownikom jednostek organizacyjnych JST. Udzielając zarządowi takiego upoważnienia, organ stanowiący jest zobligowany w uchwale budżetowej wskazać, jakiego rodzaju uprawnienia do dokonywania przeniesień planowanych wydatków budżetowych mogą być przekazane kierownikom jednostek budżetowych, określając rodzaje wydatków i poziom klasyfikacji budżetowej, na jakim zmiany te będą mogły być dokonywane. Ostatecznie o zakresie przekazanych uprawnień zadecyduje zarząd, działając w granicach udzielonego mu upoważnienia. Organ ten, jako sprawujący nadzór nad realizacją budżetu i jednocześnie odpowiedzialny za jego wykona- 
nie, musi mieć realny wpływ na przebieg tego procesu. Kierownicy jednostek budżetowych dokonujący w ramach przyznanych im uprawnień przeniesień planowanych wydatków mają obowiązek wprowadzić odpowiednie zmiany w planach finansowych, które stanowią podstawę gospodarki finansowej tych jednostek i poinformować zarząd o dokonanych przeniesieniach. Przekazywane informacje pozwalają zarządowi kontrolować zmiany w budżecie i związane z tym działania kierowników jednostek.

Jak widać, w świetle obowiązujących regulacji prawnych zarówno organ stanowiący, jak i organ wykonawczy JST posiadają kompetencje do dokonywania zmian budżetu oraz zmian w budżecie. Kryterium przesądzającym o przypisaniu kompetencji do danego organu jest rodzaj dokonywanych zmian, a nie ich zakres, przy czym każda ze zmian może być dokonana tylko z inicjatywy organu wykonawczego. W każdym przypadku rodzaj inicjowanych zmian przesądza o właściwości organu do ich przeprowadzenia. Właściwość tę należy ustalić przy jednoczesnym uwzględnieniu przepisów ustaw o ustroju samorządu terytorialnego oraz ustawy o finansach publicznych, mając przy tym na uwadze ewentualne upoważnienia udzielone przez organ stanowiący zarządowi JST do dokonywania zmian w budżecie uchwalonym na dany rok. Prawnie ukształtowany model rozdziału kompetencji w zakresie dokonywania zmian budżetu między organy samorządu terytorialnego powinien sankcjonować pozycję prawną zarządu jako wykonawcy budżetu, ponoszącego odpowiedzialność za gospodarkę finansową JST i wykonanie budżetu.

Kompetencje organów JST w zakresie dokonywania zmian budżetu i zmian $\mathrm{w}$ budżecie $\mathrm{w}$ trakcie roku budżetowego nie są jednolicie postrzegane nie tylko w literaturze przedmiotu, ale również w orzecznictwie regionalnych izb obrachunkowych oraz sądów administracyjnych. Głównym przedmiotem kontrowersji są uprawnienia organu stanowiącego do decydowania o zakresie zmian w stosunku do projektu tych zmian zgłoszonego przez organ wykonawczy, a prezentowane poglądy są zróżnicowane. Mimo że poglądy te sformułowane zostały w części na podstawie regulacji prawnych ustawy z dnia 30 czerwca 2005 r. o finansach publicznych $^{11}$, która przestała obowiązywać, nie tracą one jednak na aktualności na gruncie nowej ustawy o finansach publicznych z 2009 r. Należy bowiem zauważyć, że ograniczenia dla organu stanowiącego JST w procesie podejmowania uchwały budżetowej w stosunku do projektu przedłożonego przez organ wykonawczy, wynikające z art. 183 ust. 2 u.f.p. z 2005 r., zostały przeniesione do obecnego art. 240 ust. 2 u.f.p. z 2009 r., natomiast treść dawnego art. 179 u.f.p. z 2005 r., dotycząca wyłącznej kompetencji zarządu JST do przygotowania projektu uchwały budżetowej, a także inicjatywy w sprawie jej zmian, koresponduje $\mathrm{z}$ treścią obecnego art. 233 u.f.p. Inicjatywa zmian w uchwalonym budżecie, należąca do wyłącznej kompetencji organu wykonawczego, według jednych oznacza,

${ }^{11}$ Dz. U. Nr 249, poz. 2104 ze zm. (dalej: u.f.p. 2005). 
że organ stanowiący może tylko proponowane zmiany uwzględnić lub odrzucić. Natomiast wszelkie inne zmiany wykraczające poza propozycje zarządu winny być $\mathrm{z}$ nim uzgodnione ${ }^{12}$. Według innych opinii brzmienie powyższych przepisów wskazuje tylko, że organ stanowiący JST nie może przystąpić do prac zmierzających do zmiany uchwały budżetowej bez inicjatywy organu wykonawczego tej jednostki, przejawiającej się w przygotowaniu projektu zmiany takiej uchwały i skierowaniu takiego projektu pod obrady organu stanowiącego. Oceniając natomiast kompetencje organu stanowiącego do dokonywania zmian w uchwale budżetowej na podstawie przedłożonego projektu, należy wziąć pod uwagę także przepis art. 240 ust. 2 u.f.p., który wyznacza granice, w jakich organ stanowiący może uchwalić zmiany w sposób odmienny w stosunku do objętych inicjatywą zarządu. Przepis ten nie daje podstaw do sformułowania tezy, że organ stanowiący, dokonując zmiany uchwały budżetowej, może tylko przyjąć proponowany projekt w całości lub też projekt ten w całości odrzucić. Rola organu uchwałodawczego sprowadziłaby się bowiem w takim przypadku jedynie do udzielenia kontrasygnaty. Takie stanowisko byłoby jednak sprzeczne z uchwałodawczą rolą tego organu, zagwarantowaną odpowiednimi przepisami ustaw ustrojowych oraz brzmieniem art. 240 ust. 2 u.f.p., który zakazuje organowi stanowiącemu wprowadzania zmian w projekcie uchwały budżetowej bez zgody organu wykonawczego jedynie w dwóch przypadkach: 1) jeżeli powodowałyby one zmniejszenie dochodów jednostki lub 2) jeżeli powodowałyby one zwiększenie wydatków, jeśli w każdym z tych przypadków prowadziłoby to jednocześnie do zwiększenia deficytu jednostki. Skoro zatem - według zwolenników tego poglądu - ustawodawca wyraźnie wymienia sytuacje, w których organ stanowiący nie może podjąć uchwały sprzecznej ze stanowiskiem organu wykonawczego, należy przyjąć, że we wszystkich pozostałych przypadkach, nieobjętych hipotezą powołanego przepisu (art. 240 ust. 2 u.f.p. 2009), organ stanowiący może podejmować uchwały niezgodne $\mathrm{z}$ wnioskami organu wykonawczego, a zatem może dokonywać zmian $\mathrm{w}$ budżecie również $\mathrm{w}$ zakresie wykraczającym poza inicjatywę organu wykonawczego ${ }^{13}$.

Przeciwnicy takiego poglądu eksponują odmienność zasad uchwalania budżetu i uchwalania zmian w budżecie i wynikającej stąd zasady, że organ stanowiący JST nie może korzystać niejako „przy okazji” rozpatrywania zgłoszonych w projekcie zmian i wprowadzać własnych poprawek w obszarach nieobjętych tym projektem ${ }^{14}$. Podnoszą, że art. 240 ust. 2 u.f.p. odnosi się jedynie do po-

${ }_{12}$ Por. uchwałę nr 25/102/2008 Kolegium Regionalnej Izby Obrachunkowej w Łodzi z dnia 14 sierpnia 2008 r., OwSS 2008, nr 4, poz. 102.

${ }_{13}$ Zob. wyrok WSA z dnia 4 grudnia 2009 r., I SA/Op 445/09, OwSS 2010, nr 2, s. 81-89 i przywołane w uzasadnieniu wyroku orzecznictwo sądowe; wyrok NSA z dnia 16 lutego 2011 r., II GSK 224/10, OwSS 2011, nr 3, s. 80 wraz z glosą krytyczną Ryszarda P. Krawczyka, „Samorząd Terytorialny" 2012, nr 1-2, s. 149 i n.

${ }^{14}$ R. P. Krawczyk, op. cit., s. 150. 
dejmowania uchwały budżetowej na dany rok, nie ma natomiast zastosowania do uchwalania zmian w uchwale budżetowej, co wynika z literalnego brzmienia tego przepisu. Dokonywanie wykładni przepisów kompetencyjnych w sposób rozszerzający jest niedopuszczalne. Nie oznacza to jednak, że organ stanowiący jest pozbawiony możliwości decydowania o ostatecznym kształcie proponowanych zmian w uchwale budżetowej, z tym że nie mogą one wykraczać poza przedmiot projektu zmian zgłoszonych przez organ wykonawczy. Stanowisko takie podzielił również w jednym z wyroków NSA ${ }^{15}$, który stwierdził, że organ stanowiący, uchwalając zmiany w budżecie na podstawie przedstawionego projektu, nie może wprowadzić poprawek w zakresie nieobjętym tym projektem. W szczególności brak jest podstaw do przyjęcia, że w przypadku gdy organ wykonawczy wystąpi $\mathrm{z}$ inicjatywą zmian $\mathrm{w}$ budżecie w ściśle określonym zakresie, organ stanowiący ma możliwość wprowadzenia zmian także w części budżetu nieobjętej wnioskiem. Przy dopuszczeniu takiej możliwości dochodziłoby do istotnego ograniczenia ustawowej kompetencji organu wykonawczego - inicjatywy w sprawie zmian uchwały budżetowej. Inicjatywa organu wykonawczego dotycząca zmian w uchwale budżetowej wyznacza organowi stanowiącemu ramy, w których może nadać tej uchwale określony kształt. NSA jednocześnie podkreślił, że uprawnienia organu stanowiącego do wprowadzania zmian są zróżnicowane na etapie uchwalania uchwały budżetowej i na etapie dokonywania jej zmian. Stąd w przypadku, gdy organ stanowiący zamierza wprowadzić zmiany w budżecie, mimo braku inicjatywy organu wykonawczego, musi uzyskać jego akceptację (zgodę). Również w przypadku, gdy w wyniku wystąpienia przez organ wykonawczy z inicjatywą w sprawie zmian w budżecie organ stanowiący chce wprowadzić w nim zmiany nieobjęte tą inicjatywą, musi uzyskać zgodę organu wykonawczego.

Akceptując to stanowisko, należy dodatkowo zauważyć, że wszystkie zmiany nie tylko w budżecie, lecz także zmiany budżetu dokonywane w trakcie roku budżetowego, zarówno przez organ stanowiący, jak i organ wykonawczy, trzeba traktować jako związane z wykonywaniem budżetu, który to proces jest bezpośrednio powiązany z realizacją zadań JST. Wprowadzanie zmian do budżetu jest ważnym elementem ciągu działań podejmowanych przez zarząd w celu wykonania tego planu finansowego, co znajduje też potwierdzenie w praktyce. Uwarunkowania dotyczące realizacji zadań danej JST w roku budżetowym oraz związane z tym wymogi mają wpływ na ewentualną potrzebę dokonywania zmian budżetu. Organem wykonującym budżet i ponoszącym odpowiedzialność z tego tytułu jest zarząd JST i dlatego ten organ ma wyłączną inicjatywę w przedmiocie dokonywania zmian budżetu, jak i zmian w budżecie (art. 233 pkt 3 u.f.p., art. 60 ust. 2 pkt 4 u.s.g., art. 60 ust. 2 pkt 4 u.s.p. i art. 70 ust. 2 pkt 4 u.s.w.), z tym że niektórych z tych zmian może dokonywać samodzielnie, inne natomiast wymagają akceptacji organu stanowiącego. Występując z inicjatywą, organ wykonawczy musi określić

${ }^{15}$ Zob. wyrok NSA z dnia 20 stycznia 2010 r., II GKS 276/09, LEX nr 1103615. 
nie tylko rodzaj proponowanych zmian, lecz także ich zakres (wielkość), wyznaczając tym samym ramy możliwych zmian. Akceptacja dla dokonywania zmian $\mathrm{w}$ budżecie przez organ stanowiący w zakresie nieobjętym projektem bez zgody organu wykonawczego prowadzi do istotnego ograniczenia ustawowej kompetencji zarządu JST w zakresie inicjatywy w sprawie zmiany uchwały budżetowej i - co należy dodać - pozostaje w sprzeczności z pozycją prawną tego organu jako wykonawcy budżetu. Związanie organu stanowiącego inicjatywą organu wykonawczego dotyczącą zmian budżetu nie oznacza jednak braku możliwości decydowania przez ten organ o ostatecznym kształcie zaproponowanych zmian. Organ stanowiący może bowiem nie tylko dokonać zmian w uchwale budżetowej zgodnie z przedłożonym projektem, bądź też zmiany te w całości lub w części odrzucić, ale również może przesądzić o wymiarze ilościowym (wartościowym) każdej ze zmian w granicach łącznej ich wielkości wynikającej z projektu. Każde odejście od projektu powinno uzyskać akceptację organu wykonawczego. Przesądzenie przez organ stanowiący o wielkościach projektowanych zmian mieści się w pojęciu uchwalania tych zmian, czyli nadania im ostatecznego kształtu.

\section{Podsumowanie}

Zarząd odpowiada za prawidłową gospodarkę finansową JST, której podstawę stanowi przyjęta na dany rok przez organ stanowiący uchwała budżetowa. Stąd organ wykonawczy zajmuje główną pozycję w procedurze wykonywania budżetu, współdziałając jednocześnie $\mathrm{z}$ organem stanowiącym w sytuacji, kiedy zachodzi potrzeba dokonania zmiany budżetu. Fakt ten ma decydujące znaczenie dla rozgraniczenia kompetencji obu tych organów. Dlatego wyłączność inicjatywy organu wykonawczego dokonania zmian nie może w efekcie prowadzić do tego, aby radni, wykorzystując tę inicjatywę, wprowadzili do budżetu własne dowolne poprawki. Organ wykonawczy, odpowiadając za realizację uchwały budżetowej, nie może być pozbawiony wpływu na zakres przedmiotowy wprowadzanych w niej zmian. Wszelkie zmiany budżetu lub zmiany w budżecie, które nie zostały objęte inicjatywą zarządu, wymagają jego akceptacji. W tym zakresie organ stanowiący nie może działać samodzielnie, bowiem byłoby to sprzeczne $\mathrm{z}$ rozdziałem kompetencji między organami JST w procedurze wykonywania budżetu, gdzie rola organu wykonawczego jest wiodąca. 